\title{
Sistem Informasi Penjualan PT Surya Multi Cipta
}

\author{
Ari Kumbang ${ }^{1)}$, Arie Kusumawati ${ }^{2}$ \\ Sistem Informasi, Fakultas Industri Kreatif Institut Teknologi dan Bisnis Kalbis \\ Jalan Pulomas Selatan Kav. 22, Jakarta 13210 \\ ${ }^{1)}$ Email: kumbang.ari@gmail.com \\ ${ }^{2)}$ Email: arie.kusumawati@kalbis.ac.id
}

\begin{abstract}
PT Surya Multi Cipta is a company engaged in manufacturing machine. Sales process at PT Surya Multi Cipta still rely on Microsoft Office and Excel for recording sales and other data. Reporting process is often hampered due to the data must be searched manually, so that required sales information system. The purpose of research is to build information systems sales of PT. Surya Multi Cipta to solve systematic sales and report problems. The method used by researcher to make sales information system is System Development Life Cycle (SDLC) with prototype method and system modeling using Unified Modeling Language (UML). Sales information system created using laravel framework and programming language PHP, JavaScript and MySQL database. The results of this research is a websitebased sales information system that helps in the process of selling. Based on the results of testing and evaluation of researchers, sales information system is able to help the business process running.
\end{abstract}

keywords: information, sales, SDLC, system, UML

\begin{abstract}
Abstrak: PT Surya Multi Cipta merupakan persahaan yang bergerak di bidang penyedia mesin manufaktur. Proses penjualan pada PT Surya Multi Cipta masih mengandalkan Microsoft Office dan Excel untuk pencatatan penjualan dan data-data lainnya. Proses laporan sering terhambat akibat data-data harus dicari secara manual, sehingga dibutuhkan sistem informasi penjualan. Tujuan penelitian adalah membangun sistem informasi penjualan PT. Surya Multi Cipta untuk mengatasi masalah penjualan dan laporan secara tersistem. Metode yang digunakan peneliti untuk membuat sistem informasi penjualan adalah System Development Life Cycle (SDLC) dengan metode prototype dan pemodelan sistem menggunakan Unified Modelling Language (UML). Sistem informasi penjualan dibuat menggunakan framework laravel dan bahasa pemograman PHP, JavaScript dan database MySQL. Hasil dari penelitian ini adalah sistem informasi penjualan berbasis website yang membantu dalam melakukan proses penjualan. Berdasarkan hasil pengujian dan evaluasi dari peneliti, sistem informasi penjualan mampu membantu proses bisnis yang berjalan.
\end{abstract}

Kata kunci: informasi, penjualan, SDLC, sistem, UML

\section{PENDAHULUAN}

Sistem informasi terbagi menjadi dua kata sistem dan informasi. Sistem merupakan kumpulan prosedur atau tata cara yang telah disepakati secara bersama untuk membentuk satu kesatuan dalam mencapai suatu tujuan. Informasi merupakan kumpulan data yang digabungkan menjadi satu kesatuan kemudian dijadikan menjadi pengetahuan. Sistem informasi merupakan kumpulan kerangka kerja yang saling mengkoordinasikan antara manusia dan komputer untuk mencapai tujuan perusahaan [1]. Penjualan merupakan kegiatan transaksi yang dilakukan oleh dua belah pihak menggunakan alat pembayaran yang sah. Sistem informasi penjualan merupakan sistem yang terdiri dari sekelompok orang, peralatan dan prosedur yang tergabung dalam sebuah sistem dimana mesin (komputer) yang melakukan pekerjaan dan manusia yang mengoperasikannya untuk menjadi informasi [2].PT. Surya Multi Cipta merupakan perusahaan yang bergerak dibidang jasa penyedia mesin manufaktur, beberapa mesin yang disediakan antara lain CNC Lathe, Hand blasting, polishing, dan beberapa mesin lainnya, selain itu PT.

Surya Multi Cipta juga menyediakan jasa service jika terjadi kerusakan. Proses penjualan yang berjalan saat ini di dalam perusahaan adalah saat ada order masuk akan langsung dicek ke supplier apakah mesin yang dicari ada atau tidak, jika ada client akan langsung diberikan informasi bahwa mesin yang dicari tersedia, setelah itu dari pihak supplier akan diberikan surat jalan untuk mengantarkan mesin 
sampai tujuan.Berdasarkan hasil wawancara yang telah dilakukan kepada direktur PT. Surya Multi Cipta, perusahaan mereka belum mengotomasi sistem dalam perusahaan. Perusahaan menggunakan Microsoft excel untuk menyimpan data client dan supplier, dan menyimpan data penjualan. Perusahaan mulai kewalahan karena blm dilakukan otomasi sistem untuk kegiatan seperti membuat surat pengiriman, membuat invoice, menerima order baru, membuat laporan hasil penjualan, dll.

Beberapa kendala yang dihadapi adalah masalah dalam melakukan pencarian data client dan supplier yang terdapat di sheet yang berbeda-beda, dimana harus membuka satu persatu yang menghambat beberapa proses seperti, penentuan harga mesin, pembuatan laporan penjualan bulanan yang memakan waktu 1 sampai 2 hari, dan dapat terjadi kesalahan yang tidak disengaja seperti salah memasukan harga mesin karena tidak teliti dan terjadi redudansi data. Dari uraian permasalahan tersebut peneliti ingin membuat sistem informasi yang dapat mengatasi masalah dalam proses penjualan yang selama ini berlum terotomatisasi.

\section{METODOLOGI PENELITIAN}

Berikut ini merupakan langkah-langkah metodologi yang dilakukan peneliti untuk membuat sistem informasi penjualan, penelitian ini menggunakan model prototype. Prototype merupakan salah satu model yang terdapat pada SDLC dimana sistem dibuat menjadi beberapa model. Pembuatan sistem menggunakan prototype tidak mencoba untuk membuat sistem secara utuh, dimana hanya menaruh beberapa fitur. Penambahan fitur dilakukan dari hasil review oleh user dan developer, proses penambahan fitur akan terus berlangsung hingga user menyetujui sistem tersebut. Model prototype terdapat beberapa kasus yang dapat ditemui, dalam kasus pertama ada yang ingin sistem hanya berisi dengan fitur yang paling diminati. Dalam kasus yang kedua ada yang ingin hanya skala kecil dari keseluruhan sistem. Gambar 1 merupakan alur dari model prototype [3].

Pada awal penelitian, peneliti merumuskan masalah yang terjadi dan melakukan pengumpulan data. Peneliti melakukan tiga tahapan dalam pengumpulan data yaitu: Observasi mengenai proses bisnis dan kendala yang dihadapi; Wawancara mengenai proses bisnis, kendala yang dihadapi, kebutuhan persusahaan dan sistem yang diinginkan; dan Studi literatur mengenai penelitian terdahulu, sistem informasi penjualan, sistem informasi, penjualan, basis data, perancangan sistem, pengujian sistem dan Laravel.

Tahapkedua penelitimelakukan analisa masalah, analisa masalah dilakukan dengan melakukan analisa proses bisnis yang berjalan sehingga dapat menentukan kebutuhan funsional dan non fungsional untuk sistem.

Tahap ketiga peneliti melakukan pembuatan prototype, pada tahap ini peneliti melakukan tiga tahapan dalam pembuatan prototype yaitu: Melakukan perancangan antar muka menggunakan Balsamiq;

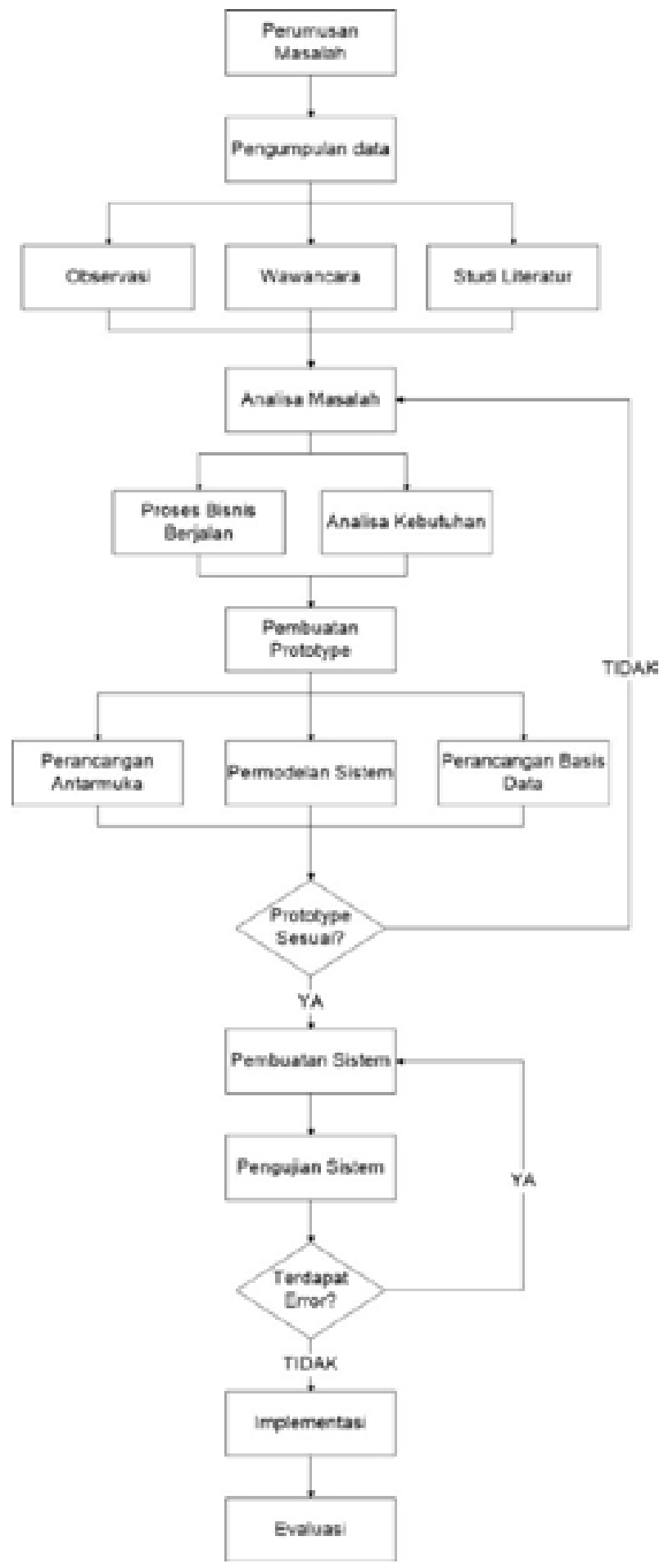

Gambar 1 Metodologi penelitian 
Perancangan basis data menggunakan ERD CDM dan ERD PDM; Permodelan sistem menggunakan use case, activity diagram, class diagram dan sequence diagram

Tahap ketiga peneliti membuat sistem berdasarkan prototype yang telah disetujui. Pada pembuatan sistem peneliti menggunakan framework Laravel untuk kerangka sistem, untuk koneksi basis data menggunakan MySQL, dan untuk bahasa pemrograman menggunakan PHP dibantu dengan JavaScript, HTML, dan Bootstrap.

Tahap keempat peneliti melakukan pengujian sistem. Pengujian sistem yang dilakukan peneliti menggunakan alpha testing, penggunaan alpha testing dilakukan untuk mendeteksi error yang terjadi pada sistem.

Tahap kelima peneliti melakukan implementasi sistem, implementasi sistem dilakuan dengan melakukan hosting, dalam melakukan implementasi peneliti melakukan dua langkah yaitu: Melakukan pembelian hosting dengan domain www. suryamulticipta.com; dan Memindahkan data data pengkodean dan basis data yang telah dibuat ke dalam hosting.

Jika tahap-tahap tersebut telah selesai dilakukan dan sesuai, sistem informasi penjualan dapat berjalan, peneliti melakukan evaluasi dari hasil implementasi sistem untuk memantau kinerja sistem.

\section{A. Penelitian Terdahulu}

Sebelum melakukan penelitian, peneliti mengumpulkan beberapa penelitian terdahulu untuk menjadi acuan dalam peanelitian, dari hasil pencarian yang dilakukan ditemukan tiga penelitian yang telah dibuat sebelum peneliti melakukan penelitian yaitu: 1) Penelitian terdahulu yang dibuat oleh Suma Handaira Putri, dan Herry Mulyono dengan judul Analisa dan Perancangan Sistem Informasi Penjualan berbasis Web (Studi Kasus: UD. CAKRA MOTOR). Sistem tersebut mencakup pengolahan data customer, pengolahan data kendaraan, pengolahan data transaksi, dan pencetakan laporan [4]; 2) Penelitian terdahulu yang dibuat oleh Sandy Kosasi dengan judul Perancangan Sistem Informasi Penjualan Berbasis Web dalam Memasarkan Mobil Bekasi. Sistem tersebut mencakup pendaftaran member, update member, dan informasi kendaraan [5]; dan 3) Penelitian terdahulu yang dibuat oleh Henrik Setyo Utomo, Rabini Sayydati, Oki Rahmanto dengan judul Implementation of Mobile-Based Monitoring Sales System in Semi Tani Shop. Sistem tersebut mencakup perhitungan laba rugi dan stok persediaan [6].

\section{HASIL DAN PEMBAHASAN}

Membahas tentang perancangan sistem informasi penjualan meliputi proses bisnis yang berjalan, kebutuhan sistem, perancangan UML (use case, activity diagram, class diagram, sequence diagram), perancangan basis data dan perancangan antar muka sistem, implementasi sistem.

\section{A. Proses Bisnis Berjalan}

proses bisnis merupakan bagaimana sebuah perusahaan menjalankan proses dalam melakukan kegiatan bisnis, berikut merupakan penjelasan proses bisnis. Berikut merupakan urutan proses bisnis yang berjalan: 1) Customer melakukan pemesanan mesin; 2) PT SMC menerima pesanan dan menghubungi supplier untuk menanyakan mesin yang sedang dicari; 3) Supplier melakukan pengecekan mesin yang dicari; 4) Supplier memberikan informasi ke PT SMC jika mesin tersebut ada dan tidak ada; 5) PT SMC memberitahukan ke customer jika mesin ada dan tidak ada untuk konfirmasi pesanan selanjutnya; 6) Jika mesin tidak ada customer akan membatalkan pesanan mesin, jika mesin ada customer akan mengkonfirmasi pesanan mesin dan melakukan pembayaran; 7) Setelah melakukan proses

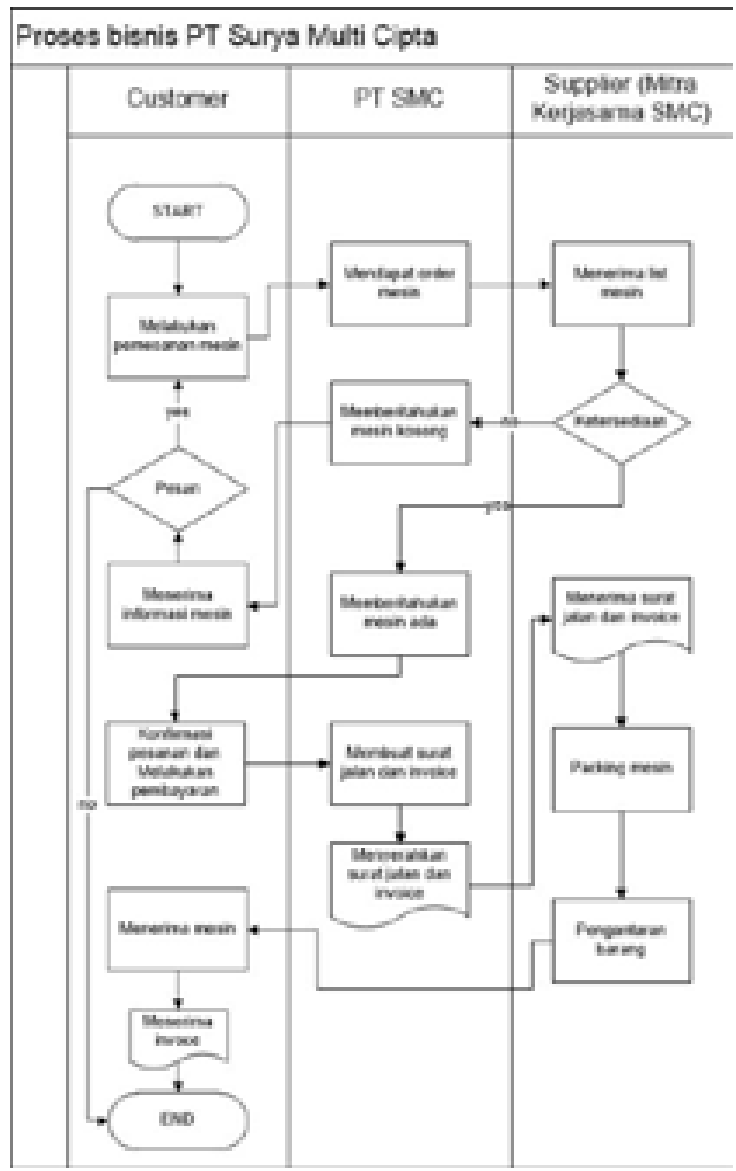

Gambar 2 Proses bisnis berjalan 
pembayaran pihak PT SMC membuatkan surat jalan beserta invoice pembelian yang akan diserahkan ke supplier untuk diantar; dan 8) Supplier melakukan packing mesin, seteleah itu melakukan pengantaran hingga ke tempat hingga mesin telah diterima oleh customer.

Penggambaran proses bisnis yang sedang berjalan saat ini dapat dilihat pada Gambar 2 .

\section{B. Analisa Kebutuhan}

Analisa kebutuhan meliputi penentuan kebutuhan funsional dan non funsional untuk sistem informasi penjualan pada PT Surya Multi Cipta.

\section{Kebutuhan Funsional}

Kebutuhan funsional adalah kebutuhan dimana berisi proses-proses yang berjalan didalam sistem. Sistem informasi penjualan PT. Surya Multi Cipta digunakan oleh bagian sales, procurement, dan pemilik. Setiap kebutuhan akan berbeda beda dengan setiap bagian. Untuk dapat mengakses menu, setiap pengguna harus melakukan login terlebih dahulu Berikut ini merupakan kebutuhan funsional yang terdapat pada Tabel 1 sampai Tabel 4.

Tabel 1 merupakan kebutuhan fungsional untuk sales dimana sales dapat ke menu customer dan penjualan. Pada menu customer, sales dapat menambah, mengubah dan menghapus data customer. Pada menu penjualan, sales dapat menambah dan menghapus data penjualan.

Tabel 1 Kebutuhan fungsional sales

\begin{tabular}{ll}
\hline \hline Fungsi & Fitur \\
\hline Login & Masuk kedalam sistem \\
\hline Data & Input, edit, delete data \\
Customer & $\begin{array}{l}\text { customer } \\
\text { Menampilkan data customer }\end{array}$ \\
\hline Data & Input penjualan \\
Penjualan & Menampilkan data penjualan \\
& Menghapus data penjualan \\
& Mencetak Penjualan \\
\hline
\end{tabular}

Tabel 2 merupakan kebutuhan fungsional untuk procurement dimana procurement dapat ke menu customer dan penjualan. Pada menu supplier, procurement dapat menambah, mengubah dan menghapus data supplier. Pada menu mesin, procurement dapat menambah, mengubah dan menghapus data mesin.

Tabel 3 merupakan kebutuhan fungsional untuk pemilik dimana pemilik dapat ke menu customer, penjualan, pengguna, karyawan, supplier, dan mesin. Pemilik hanya dapat melihat data-data untuk menu penjualan pemilik dapat mencetak laporan.
Tabel 2 Kebutuhan fungsional procurement

\begin{tabular}{ll}
\hline \hline Fungsi & Fitur \\
\hline Login & Masuk kedalam sistem \\
\hline Data & Input, edit, delete data \\
Supplier & Supplier \\
& Menampilkan data Supplier \\
\hline Data & Input, edit, delete data \\
Mesin & Supplier \\
& Menampilkan data Mesin \\
\hline
\end{tabular}

Tabel 3 Kebutuhan fungsional pemilik

\begin{tabular}{ll}
\hline \hline Fungsi & Fitur \\
\hline Login & Masuk kedalam sistem \\
\hline Melihat & Manampilkan laporan \\
Laporan & penjualan, data customer, data \\
& supplier, dan data mesin \\
& Mencetak Penjualan \\
\hline
\end{tabular}

Tabel 4 merupakan kebutuhan fungsional untuk admin, dimana admin dapat ke menu customer, penjualan, pengguna, karyawan, supplier, dan mesin. Admin dapat memasukan, mengubah dan menghapus data untuk menu pengguna, karyawan, customer, mesin dan supplier. Admin dapat menambah, menghapus dan mencetak pada menu penjualan.

Tabel 4 Kebutuhan fungsional admin

\begin{tabular}{ll}
\hline \hline Fungsi & Fitur \\
\hline Login & Masuk kedalam sistem \\
\hline Data & Input, edit, delete data customer \\
Customer & Menampilkan data customer \\
\hline Data & Input penjualan \\
Penjualan & Menampilkan data penjualan \\
& Menghapus data penjualan \\
& Mencetak Penjualan \\
\hline Data & Input, edit, delete data mesin \\
Mesin & Menampilkan data mesin \\
\hline Data & Input, edit, delete data supplier \\
Supplier & Menampilkan supplier \\
\hline Data & Input, edit, delete data pengguna \\
Pengguna & Menampilkan data pengguna \\
\hline
\end{tabular}

\section{Kebutuhan Non Funsional}

Kebutuhan non fungsional adalah kebutuhan yang berkaitan dengan komponen yang digunakan untuk mendukung sistem dapat berjalan. Berikut merupakan kebutuhan non fungsional yang terdapat pada Tabel 5.

\section{Pembuatan Prototype}

Pembuatan prototype sistem informasi penjualan yang dibuat oleh peneliti meliputi pembuatan UML (use case, class diagram, activity diagram dan sequence diagram), perancangan antar muka, dan perancangan basis data. 
Tabel 5 Kebutuhan non funsional sistem

\begin{tabular}{ll}
\hline \hline Komponen & Deskripsi \\
\hline Perangkat & Windows 10 Pro dengan \\
Keras & minimum spesifikasi perangkat \\
1 Unit PC & keras: \\
atau & Intel Core i3 \\
Laptop & Sistem Operasi 64-bit \\
& Kecepatan prosesor 2.00 GHz \\
& RAM sebesar 4,00 GB \\
& Hard disk (HDD) minimal 1 GB \\
\hline Perangkat & Sistem Operasi Windows 10 Pro \\
Lunak & Google Chrome 67.0.3396.87 \\
& XAMPP for Windows versi 7.1.1 \\
& Atom 1.28 \\
\hline
\end{tabular}

\section{Use Case}

Use case diagram yang menggambarkan bentuk permodelan untuk sistem informasi yang akan dibuat. Use case diagram digambarkan dengan aktor yang saling berinteraksi dengan sistem. Umumnya digunakan juga untuk mengetahui fungsi apa saja yang ada didalam sistem informasi yang akan dibuat [7]. Berikut ini merupakan rancangan usecase untuk sistem informasi penjualan yang memperlihatkan keterhubungan antara aktor dan sistem yang akan dibuat. Use case diagram terdapat 4 aktor, dan masing masing aktor harus melakukan validasi untuk menggunakan sistem tersebut, untuk aktor pemilik dapat melihat keseluruhan data, untuk aktor procurement dapat melakukan penglolaan mesin dan supplier, untuk aktor dapat melakukan pengelolaan customer dan penjualan, dan untuk admin dapat mengelola karyawan, mesin, penjualan, customer, supplier, dan mesin.

\section{Class Diagram}

Class diagram menggambarkan struktur sistem dalam mendefinisikan kelas apa saja yang akan dibuat didalam sistem. Dalam class diagram dapat menentukan sifat setiap objek [8]. Class diagram menjelaskan struktur sistem dari segi pendefinisian kelas-kelas yang dibuat untuk membangun sistem. Kelas tersebut merupakan kelas yang menjadi kelas utama dari hasil analisis yang terdapat pada use case diagram. Relasi antar kelas menjadi bagian dalam perancangan logika yang akan diimplementasikan kedalam sistem. Hasil rancangan kelas diagram terdiri dari 10 kelas utama yaitu validasi, tampilan menu, koneksi database, mengelola data penjualan, mengelola data customer, mengelola data supplier, mengelola data mesin, mengelola data karyawan, mengelola data pengguna, mengelola data penjualan serta 6 kelas data yang saling terhubung ke koneksi database yaitu data karyawan, data pengguna, data supplier, data customer, data mesin, data penjualan. rancangan class diagram.

\section{Activity Diagram}

Activity diagram atau diagram aktivitas merupakan yang menggambarkan tentang aktivitas yang terjadi pada sistem. Activity diagram menggambarkan kegiatan sistem secara berurutan [9]. Berikut ini merupakan rancangan aktivitas diagram untuk sistem informasi penjualan yang terdapat pada Gambar 3 sampai Gambar 6.

Aktivitas diagram pada Gambar 3 menunjukan aktivitas yang terjadi setelah login akan terdapat pilihan untuk melihat data karyawan, supplier, mesin, customer dan penjualan, setelah selesai melihat data terdapat pilihan seperti logout atau dapat melihat kembali data yang tersedia.

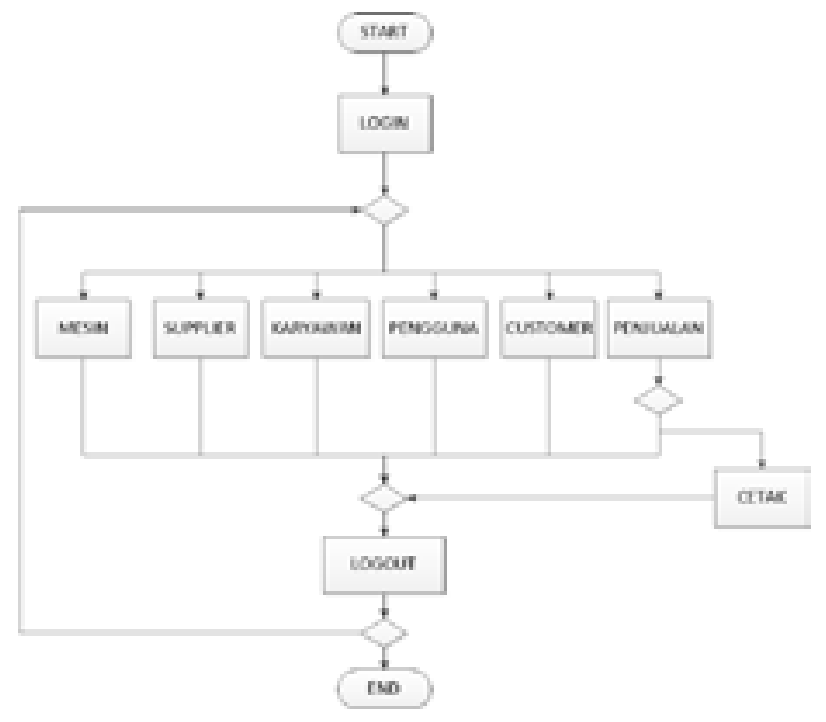

Gambar 3 Activity pemilik

Activity diagram pada Gambar 4 menunjukan aktivitas untuk pengolahan data supplier dan mesin. Terdapat dua pilihan aktivitas yang terjadisetelah login, untuk mengelola data supplier atau mesin. Aktivitas yang terjadi jika memilih menambah data supplier terdapat pilihan untuk menyimpan data baru atau batal menyimpan. Aktivitas tampilkan data supplier terdapat pilihan untuk menghapus atau mengubah. Aktivitas yang terjadi jika memilih menambah data mesin terdapat pilihan untuk menyimpan data baru atau batal menyimpan. Aktivitas tampilkan data mesin terdapat pilihan untuk menghapus atau mengubah. Setiap aktivitas menambah, menghapus dan mengubah akan disimpan kedatabase.

Activity diagram pada Gambar 5 menunjukan aktivitas untuk pengolahan data customer dan penjualan. Terdapat dua pilihan aktivitas yang terjadi setelah login, untuk mengelola data customer atau penjualan. Aktivitas yang terjadi jika memilih 


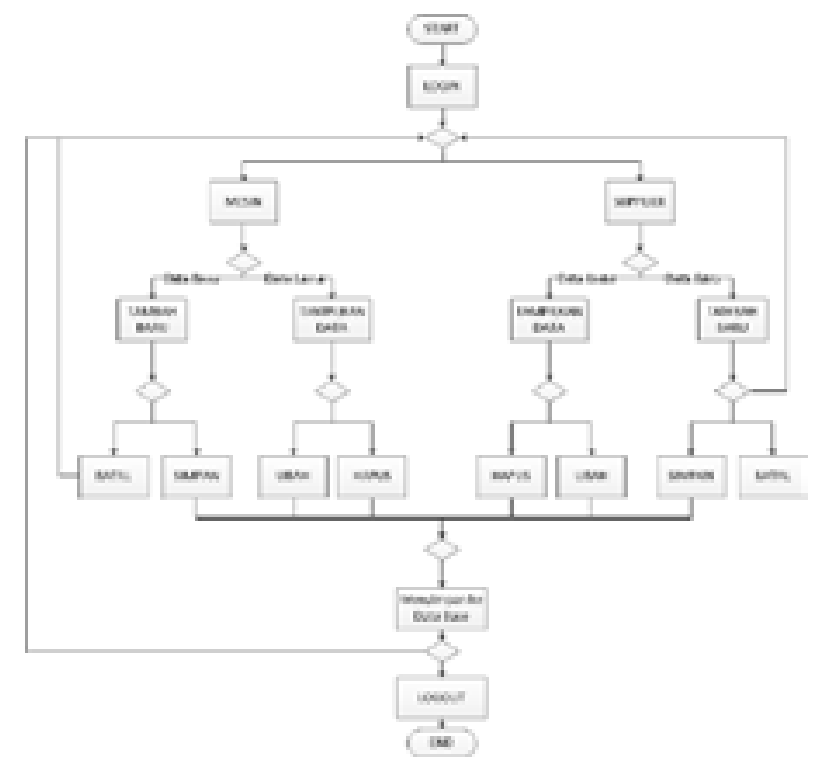

Gambar 4 Activity procurement

menambah data customer terdapat pilihan untuk menyimpan data baru atau batal menyimpan. Aktivitas tampilkan data customer terdapat pilihan untuk menghapus atau mengubah. Aktivitas yang terjadi jika memilih menambah data penjualan terdapat pilihan untuk menyimpan data baru atau batal menyimpan. Aktivitas yang terjadi jika memilih tampilkan data penjualan terdapat pilihan untuk menghapus data dan mencetak data. Setiap aktivitas menambah, menghapus ataupun mengubah akan disimpan kedatabase.

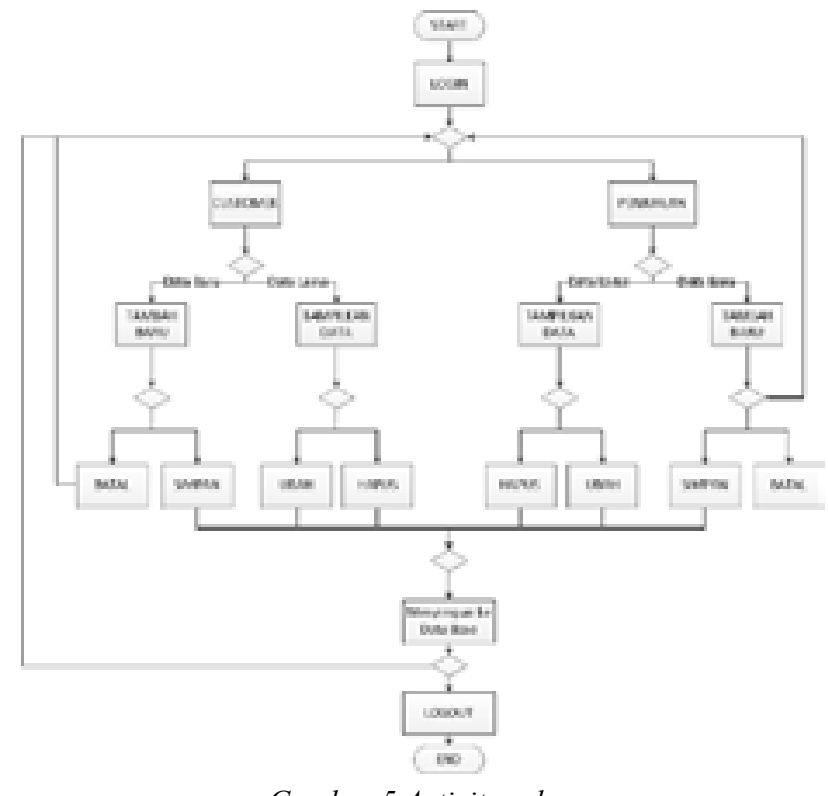

Gambar 5 Activity sales

Activity diagram pada Gambar 6 menunjukan aktivitas untuk pengolahan data karyawan dan pengguna. Terdapat dua pilihan aktivitas yang terjadi setelah login, untuk mengelola data pengguna atau karyawan. Aktivitas yang terjadi jika memilih menambah data karyawan terdapat pilihan untuk menyimpan data baru atau batal menyimpan. Aktivitas tampilkan data karyawan terdapat pilihan untuk menghapus atau mengubah. Aktivitas yang terjadi jika memilih menambah data karyawan terdapat pilihan untuk menyimpan data baru atau batal menyimpan. Aktivitas tampilkan data karyawan terdapat pilihan untuk menghapus atau mengubah. Setiap aktivitas menambah, menghapus dan mengubah akan disimpan kedatabase.

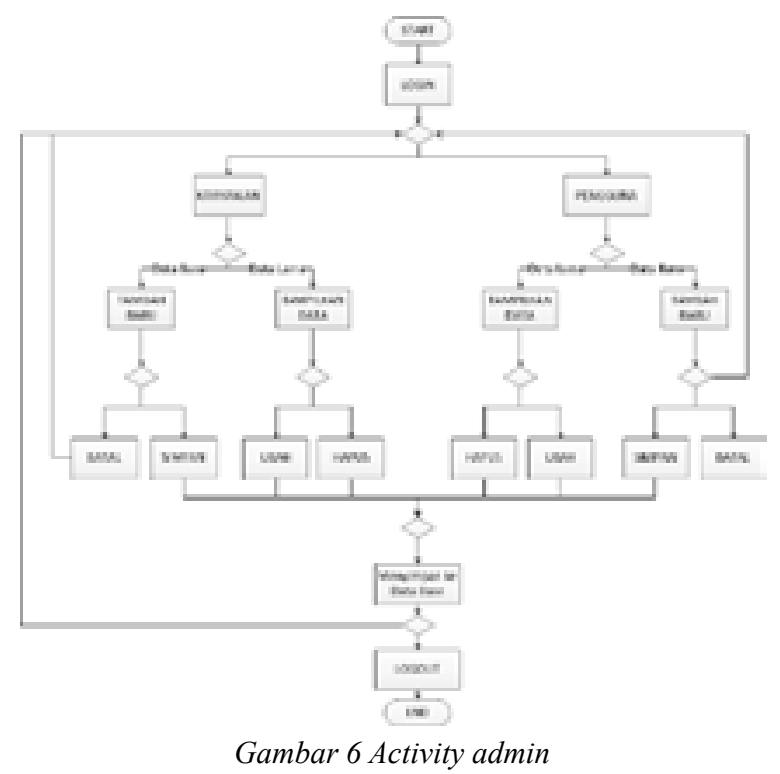

\section{Sequence Diagram}

Sequence diagram menggambarkan prilaku objek pada use case. Prilaku objek pada use case digambarkan dengan garis yang berjalan sebagai waktu hidup objek dalam menyampaikan pesan untuk objek lainnya [10]. Berikut ini merupakan rancangan sequence diagram untuk sistem informasi penjualan yang terdapat pada Gambar 9 sampai Gambar 16. Gambar 9 memperlihatkat proses login dan logout pada sistem secara umum untuk seluruh karyawan, saat login data akan dicek terlebih dahulu apakah username dan password benar, jika salah akan muncul warning, jika berhasil akan masuk ke halaman utama. proses logout akan mengirimkan informasi ke database dan akan berpindah ke menu login.

Gambar 8 menunjukan urutan dari sistem yang berjalan setelah masuk kedalam sistem. Pemilik dapat melihat seluruh data yang ada di dalam sistem.

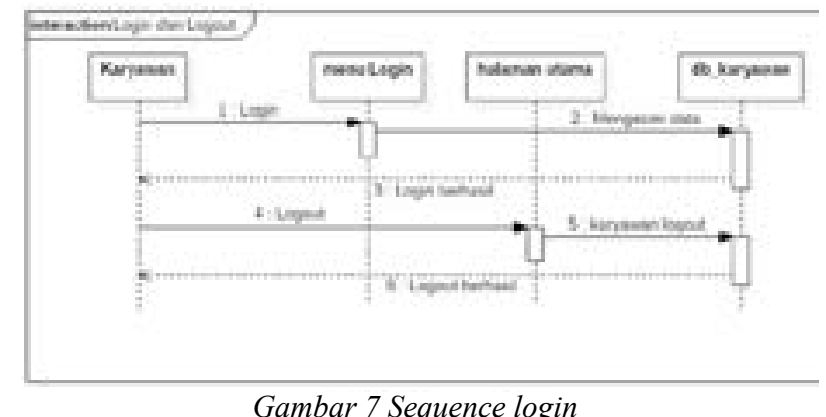

Gambar 7 Sequence login 
Saat pemilik ingin melihat data karyawan, data akan diambil dari tabel karyawan dan akan dimunculkan, jika ingin melihat data penjualan, data akan diambil dari tabel penjualan dan akan dimunculkan, jika ingin melihat data, proses tersebut akan dilakukan secara terus menerus untuk menampilkan data yang diinginkan.

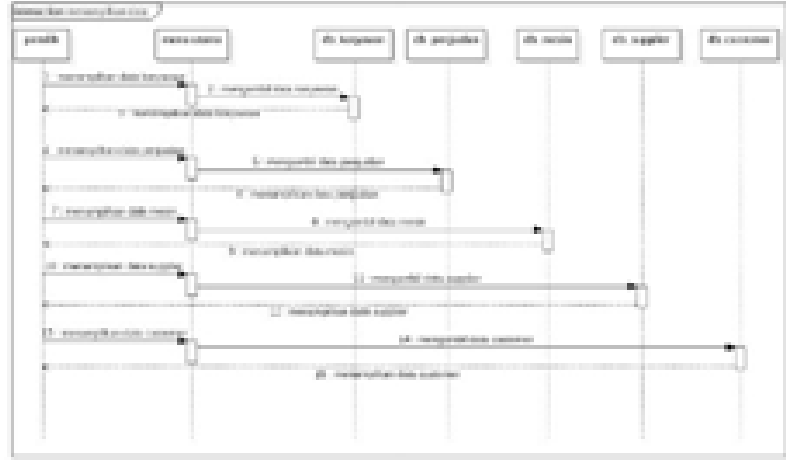

Gambar 8 Sequence melihat laporan

Gambar 9 menunjukan urutan dari sistem yang berjalan setelah masuk kedalam sistem. Admin dapat melakukan beberapa kegiatan di menu karyawan seperti menambah, mengubah dan menghapus. Untuk mengubah dan menghapus data akan mengambil data dan ditampilkan data karyawan yang ada, setelah itu memilih data yang ingin dihapus atau diubah. Perubahan data yang terjadi akan disimpan ke database.

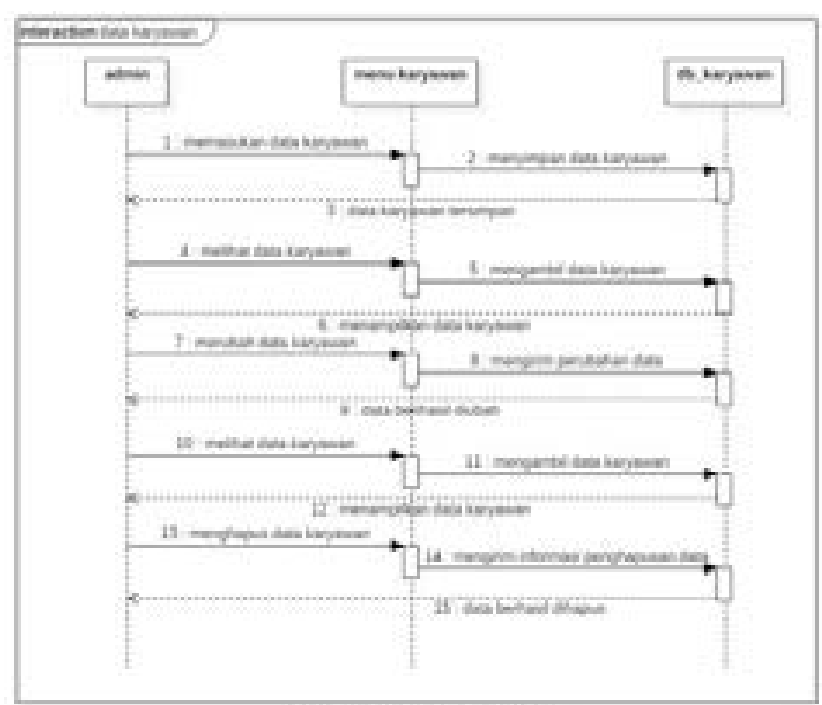

Gambar 9 Sequence karyawan

Gambar 10 menunjukan urutan dari sistem yang berjalan setelah masuk kedalam sistem. Admin dapat melakukan beberapa kegiatan di menu pengguna seperti menambah, mengubah dan menghapus. Untuk mengubah dan menghapus data akan mengambil data dan ditampilkan data pengguna yang ada, setelah itu memilih data yang ingin dihapus atau diubah. Perubahan data yang terjadi akan disimpan ke database.

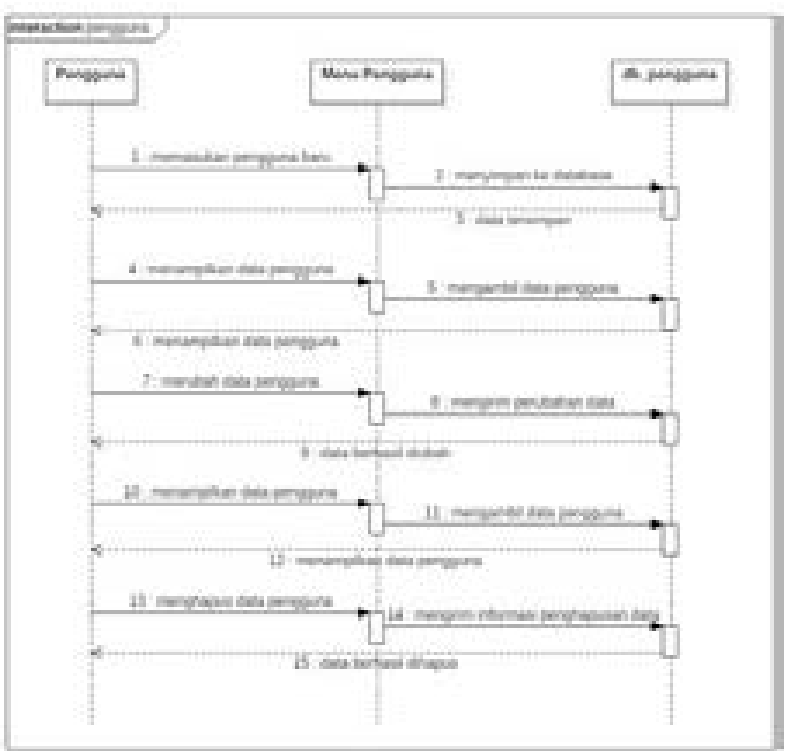

Gambar 10 Sequence pengguna

Gambar 11 menunjukan urutan dari sistem yang berjalan setelah masuk kedalam sistem. Procurement dapat melakukan beberapa kegiatan di menu mesin seperti menambah, mengubah dan menghapus. Untuk mengubah dan menghapus data akan mengambil data dan ditampilkan data mesin yang ada, setelah itu memilih data yang ingin dihapus atau diubah. Perubahan data yang terjadi akan disimpan ke database.

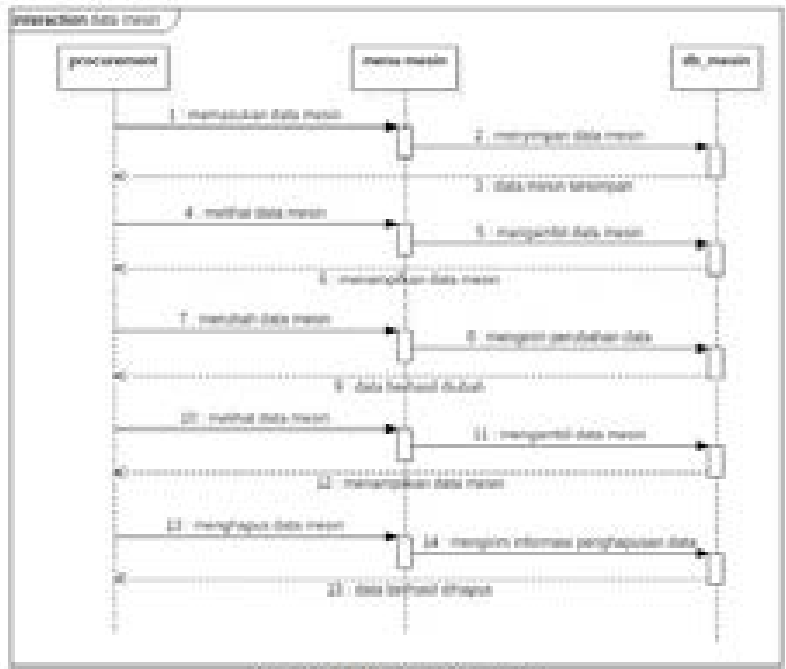

Gambar 11 Sequence supplier

Gambar 12 menunjukan urutan dari sistem yang berjalan setelah masuk kedalam sistem. Procurement dapat melakukan beberapa kegiatan di menu supplier seperti menambah, mengubah dan menghapus. Untuk mengubah dan menghapus data akan mengambil data dan ditampilkan data supplier yang ada, setelah itu memilih data yang ingin dihapus atau diubah. Perubahan data yang terjadi akan disimpan ke database.

Gambar 13 menunjukan urutan dari sistem yang berjalan setelah masuk kedalam sistem. Sales dapat 


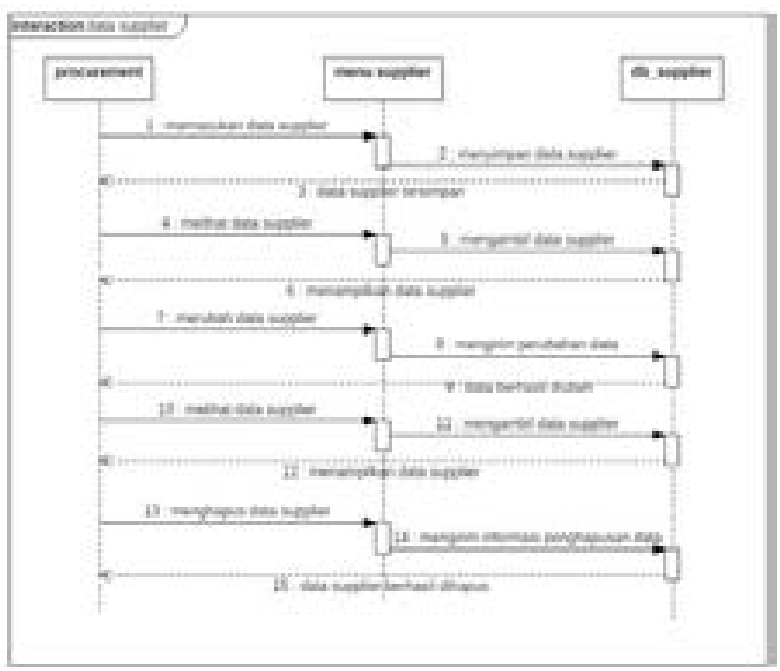

Gambar 12 Sequence mesin

melakukan beberapa kegiatan di menu customer seperti menambah, mengubah dan menghapus. Untuk mengubah dan menghapus data akan mengambil data dan ditampilkan data customer yang ada, setelah itu memilih data yang ingin dihapus atau diubah. Perubahan data yang terjadi akan disimpan ke database.

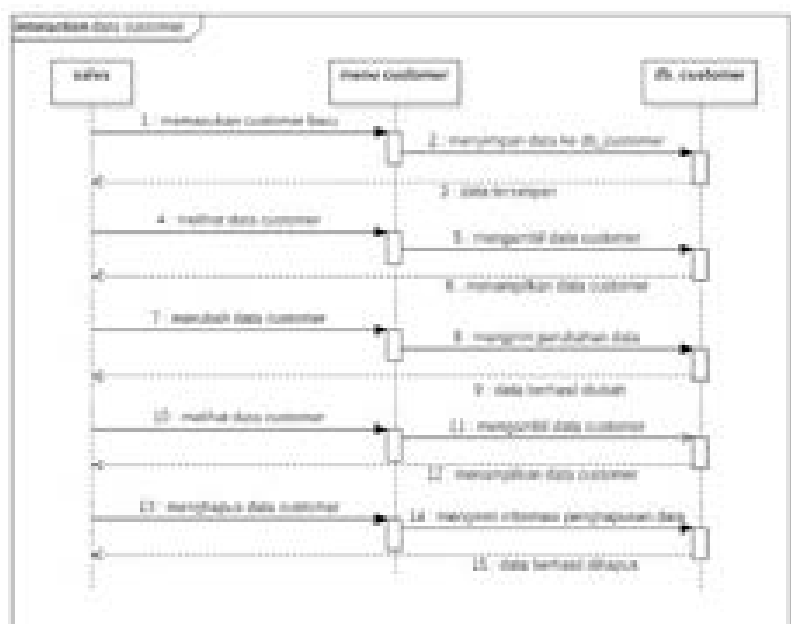

Gambar 13 Sequence customer

Gambar 14 menunjukan urutan dari sistem yang berjalan setelah masuk kedalam sistem. Sales dapat melakukan beberapa kegiatan di menu penjualan seperti menambah dan menghapus. Untuk menghapus data akan mengambil data dan ditampilkan data

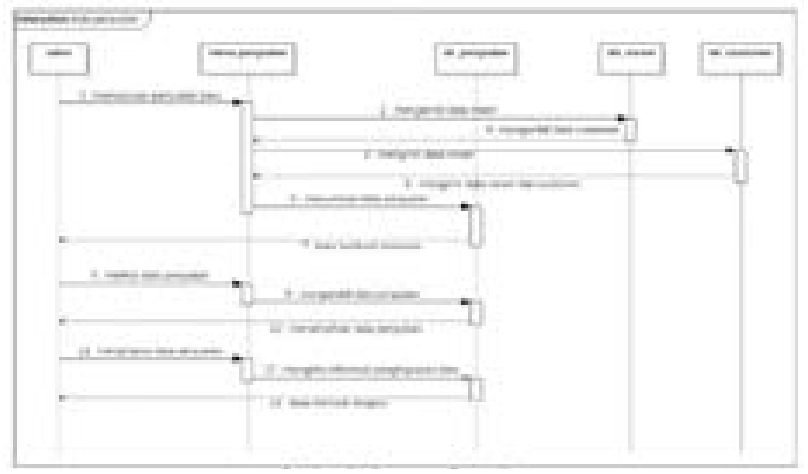

Gambar 14 Sequence penjualan penjualan yang ada, setelah itu memilih data yang ingin dihapus. Perubahan data yang terjadi akan disimpan ke database.

\section{Perancangan Basis Data}

Basis data terdiri dari 2 kata, yaitu basis dan data. Basis dapat diartikan sebagai tempat berkumpul atau markas. Data merupakan gambaran sebuah objek seperti manusia, benda, binatang yang diperlihatkan dalam bentuk angka, huruf, simbol, gambar dan sebagainya. Basis data didefinisikan jika saling terhubung, keterhubungan tersebut dapat diolah dan dimanfaatkan [11]. Berikut merupakan perancangan basis data yang digunakan oleh peneliti dalam membuat basis data sistem informasi penjualan PT Surya Multi Cipta. Gambar 22 dan Gambar 23 menjelaskan perancangan basis data. Terdapat 8 tabel didalam basis data masing-masing saling terhubung. Tabel divisi memiliki keterhubungan one to many dengan tabel karyawan. Tabel user_role memiliki keterhubungan one to many dengan tabel user. Tabel user memiliki keterhubungan one to many dengan tabel karyawan. Tabel karyawan memiliki keterhubungan one to many dengan tabel penjualan. Tabel customer memiliki keterhubungan one to many dengan tabel penjualan. Tabel mesin memiliki keterhubungan one to many dengan tabel penjualan. Tabel supplier memiliki keterhubungan one to many dengan tabel mesin.

\section{1. $C D M$}

CDM atau model konsep data merupakan gambaran dari data yang akan dijadikan basis data. CDM dibuat dalam bentuk tabel beserta dengan keterhubungannya dengan tabel lain tetapi tidak menggunakan tipe data [12]. CDM (Conceptual Data Model) menjabarkan konsep yang berkaitan dengan pandangan pemakai terhadap data yang disimpan dalam basis data, CDM dibuat sudah dalam bentuk tabel-tabel tanpa tipe data yang menggambarkan relasi antar tabel untuk keperluan implementasi ke basis data.

\section{PDM}

PDM merupakan model yang menggunakan tabel yang menggambarkan basis data dan hubungan antar tabel. PDM merupakan konsep yang menerangkan isi detail dari setiap tabel. PDM merupakan bentuk fisik perancangan basis data yang sudah siap diimplementasikan [13]. PDM (Physical Data Model) menjelaskan model yang menggunakan sejumlah tabel untuk menggambarkan 
data serta hubungan antara data. Dimana setiap tabel mempunyai sejumlah kolom dimana setiap kolom memiliki nama yang unik beserta tipe data.

\section{Sturktur Basis Data}

Berikut ini merubakan tabel yang digunakan dalam perancangan basis data yang ditunjukan sebagai berikut.

Tabel 6 menjelaskan struktur tabel basis data yang akan dibuat, terdiri dari 8 kolom dengan id sebagai primary key dan id_user_role sebagaiforeign key.

Tabel 6 Struktur tabel user

\begin{tabular}{llll}
\hline \hline Nama Kolom & Tipe Data & Ukuran & $\begin{array}{l}\text { Keteranga } \\
\text { n }\end{array}$ \\
\hline Id & Int & 11 & Primary key \\
\hline Id_user_role & Int & 11 & Foreign key \\
\hline Username & Varchar & 100 & \\
\hline Password & Varchar & 100 & \\
\hline Nama & Varchar & 100 & \\
\hline Delete_flag & Int & 1 & \\
\hline Create_at & Datetime & & \\
\hline Update_at & timestamp & & \\
\hline Last_login & datetime & & \\
\hline
\end{tabular}

Tabel 7 menjelaskan struktur tabel basis data yang akan dibuat, terdiri dari 5 kolom dengan id sebagai primary key.

Tabel 7 Struktur tabel divisi

\begin{tabular}{llll}
\hline \hline Nama Kolom & Tipe Data & Ukuran & Keterangan \\
\hline Id & Int & 11 & Primary key \\
\hline Nama_divisi & Varchar & 50 & \\
\hline Delete_flag & Int & 1 & \\
\hline Create_at & Datetime & & \\
\hline Update_at & timestamp & & \\
\hline
\end{tabular}

Tabel 8 menjelaskan struktur tabel basis data yang akan dibuat, terdiri dari 11 kolom dengan id sebagai primary key dengan id_user, dan id_divisi sebagai foreign key.

Tabel 8 Struktur tabel karyawan

\begin{tabular}{llll}
\hline \hline Nama Kolom & Tipe Data & Ukuran & Keterangan \\
\hline Id & Int & 11 & Primary key \\
\hline Nama & Varchar & 50 & \\
\hline Jenis_kelaim & enum & & \\
\hline Alamat & Varchar & 100 & \\
\hline No_telepon & Varchar & 15 & \\
\hline Email & Varchar & 50 & \\
\hline Id_user & Int & 11 & Foreign key \\
\hline Id_divisi & Int & 11 & Foreign key \\
\hline Delete_flag & Int & 1 & \\
\hline Create_at & Datetime & & \\
\hline Update_at & timestamp & & \\
\hline
\end{tabular}

Tabel 9 menjelaskan struktur tabel basis data yang akan dibuat, terdiri dari 9 kolom dengan id sebagai primary key.

Tabel 9 Struktur tabel customer

\begin{tabular}{llll}
\hline \hline $\begin{array}{l}\text { Nama } \\
\text { Kolom }\end{array}$ & Tipe Data & Ukuran & Keterangan \\
\hline Id & Int & 11 & Primary key \\
\hline Nama & Varchar & 50 & \\
\hline Alamat & Varchar & 100 & \\
\hline No_telepon & Varchar & 15 & \\
\hline Email & Varchar & 50 & \\
\hline No_npwp & Varchar & 20 & \\
\hline Delete_flag & Int & 1 & \\
\hline Create_at & Datetime & & \\
\hline Update_at & timestamp & & \\
\hline
\end{tabular}

Tabel 10 menjelaskan struktur tabel basis data yang akan dibuat, terdiri dari 9 kolom dengan id sebagai primary key.

Tabel 10 Struktur tabel supplier

\begin{tabular}{llll}
\hline \hline Nama Kolom & Tipe Data & Ukuran & Keterangan \\
\hline Id & Int & 11 & Primary key \\
\hline Nama & Varchar & 50 & \\
\hline Alamat & Varchar & 100 & \\
\hline No_telepon & Varchar & 15 & \\
\hline Email & Varchar & 50 & \\
\hline No_npwp & Varchar & 20 & \\
\hline Delete_flag & Int & 1 & \\
\hline Create_at & Datetime & & \\
\hline Update_at & timestamp & & \\
\hline
\end{tabular}

Tabel 11 menjelaskan struktur tabel basis data yang akan dibuat, terdiri dari 9 kolom dengan id sebagai primary key dengan id_supplier sebagai foreign key.

Tabel 11 Struktur tabel mesin

\begin{tabular}{llll}
\hline \hline Nama Kolom & Tipe Data & Ukuran & Keterangan \\
\hline Id & Int & 11 & Primary key \\
\hline Id_supplier & Int & 11 & Foreign key \\
\hline Nama_mesin & Varchar & 50 & \\
\hline Harga_beli & Decimal & 15,2 & \\
\hline Harga_jual & Decimal & 15,2 & \\
\hline Laba & Decimal & 15,2 & \\
\hline Delete_flag & Int & 1 & \\
\hline Create_at & Datetime & & \\
\hline Update_at & timestamp & & \\
\hline
\end{tabular}

Tabel 12 menjelaskan struktur tabel basis data yang akan dibuat, terdiri dari 14 kolom dengan id sebagai primary key dengan id_customer, id_mesin, dan id_karyawan sebagai foreign key.

Tabel 13 menjelaskan struktur tabel basis data yang akan dibuat, terdiri dari 5 kolom dengan id sebagai primary key. 
Tabel 12 Struktur tabel penjualan

\begin{tabular}{llll}
\hline \hline Nama Kolom & Tipe Data & Ukuran & Keterangan \\
\hline Id & Int & 11 & Primary key \\
\hline Id_customer & Int & 11 & Foreign key \\
\hline Id_mesin & Int & 11 & Foreign key \\
\hline Id_karyawan & Int & 11 & Foreign key \\
\hline No_do & Varchar & 20 & \\
\hline No_po & Varchar & 20 & \\
\hline Harga & Decimal & 15,2 & \\
\hline jumlah & Varchar & 11 & \\
\hline tanggal & timestamp & & \\
\hline total & Decimal & 15,2 & \\
\hline Pajak & Int & 2 & \\
\hline Delete_flag & Int & 1 & \\
\hline Create_at & Datetime & \\
\hline Update_at & timestamp & & \\
\hline
\end{tabular}

Tabel 13 Struktur tabel user role

\begin{tabular}{llll}
\hline \hline Nama Kolom & Tipe Data & Ukuran & Keterangan \\
\hline Id & Int & 11 & Primary key \\
\hline Nama & Varchar & 20 & \\
\hline Delete_flag & Int & 1 & \\
\hline Create_at & Datetime & & \\
\hline Update_at & timestamp & & \\
\hline
\end{tabular}

\section{E. Perancangan Antar Muka}

Setelah melakukan perancangan diagram UML dan database peneliti melakukan perancangan antar muka untuk sistem informasi yang akan dibuat. Pembuatan rancangan antar muka menggunakan Balsamiq. Berikut merupakan beberapa contoh perancangan sistem informasi yang telah dibuat peneliti dan telah didiskusikan dengan pihak yang terkait terdapat pada gambar 17 sampai Gambar 21.

Gambar 17 merupakan tampilan untuk login, terdapat dua kolom untuk memasukan nama dan kata sandi dan memiliki button untuk login agar dapat masuk kedalam sistem.

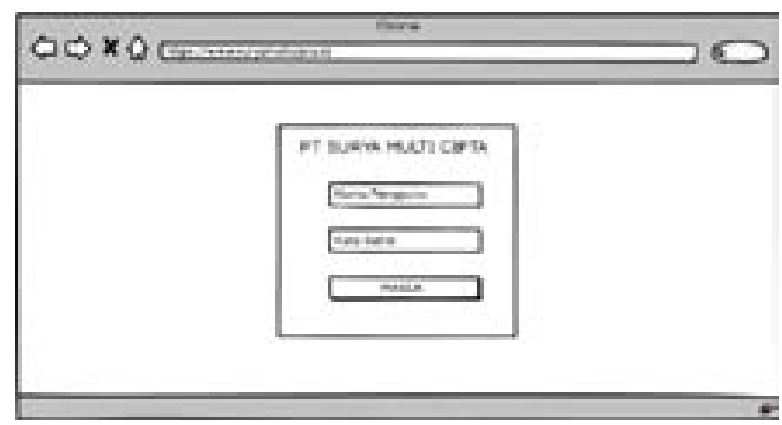

Gambar 17 Rancangan login

Gambar 18 merupakan tampilan setelah login untuk bagian Admin, pada rancangan ini untuk mengelola data pengguna. Terdapat 1 button untuk menambah pengguna baru. Tabel pengguna berisi informasi berupa Username, Nama, Role, dan Opsi.

Gambar 19 merupakan tampilan setelah login untuk bagian Sales, pada rancangan ini untuk

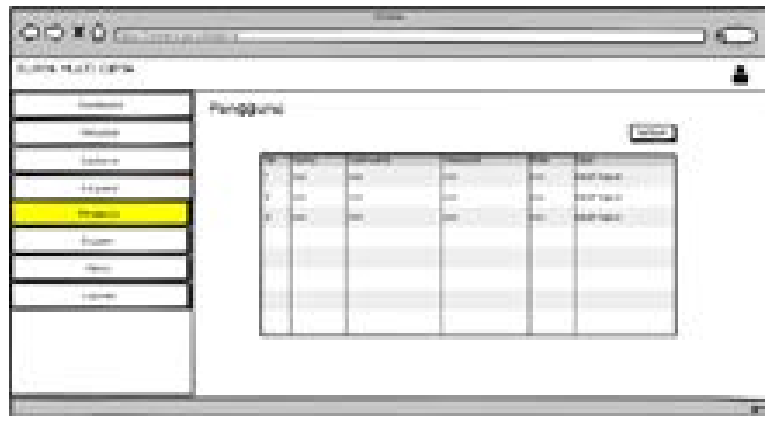

Gambar 18 Rancangan menu admin

mengelola data Penjualan. Terdapat 1 button untuk menambah penjualan baru. Tabel Penjualan berisi informasi berupa No PO, No DO, Nama Customer, Mesin, Harga, Jumlah, Tanggal pembelian, Total dan opsi.

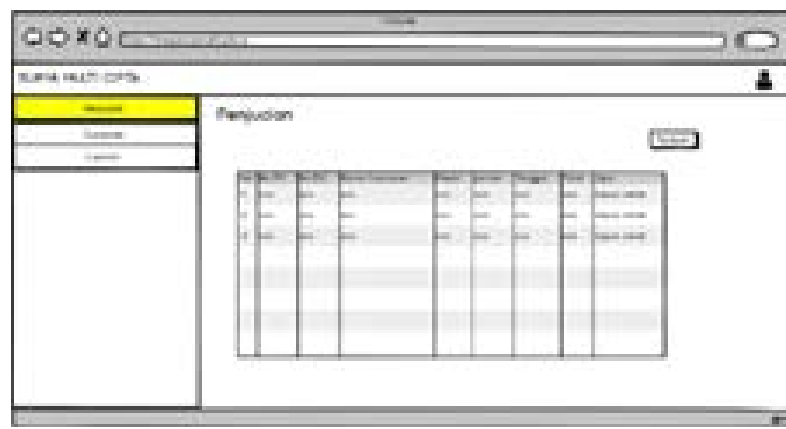

Gambar 19 Rancanga menu sales

Gambar 20 merupakan tampilan setelah login untuk bagian Procurement, pada rancangan ini untuk mengelola data Mesin. Terdapat 1 button untuk menambah Mesin baru. Tabel Mesin berisi informasi berupa Nama Mesin, Nama Supplier, Harga Beli, Harga Jual, Laba dan Opsi.

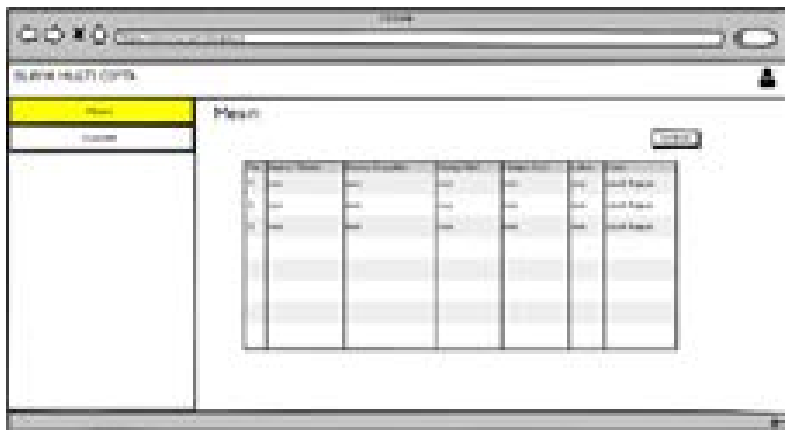

Gambar 20 Rancangan menu procurement

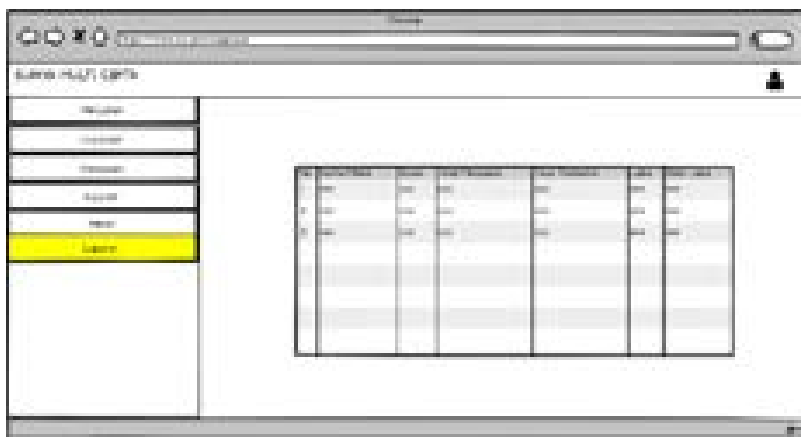

Gambar 21 Rancangan menu pemilik 
Gambar 21 merupakan tampilan setelah login untuk bagian Pemilik, pada rancangan ini untuk Melihat Laporan. Tabel Laporan berisi informasi berupa Nama Mesin, Bulan, Total Penjualan, Total Transaksi, Laba dan Total Laba.

\section{F. Pengujian}

Pengujian sistem harus menyiapkan sesi khusus untuk menguji sehingga jika terdapat kekurangan atau kesalahan dapat diperbaiki secepat mungkin. Metode yang diterapkan dalam pengujian menggunakan alpha testing. Pengujian alpha dilakukan untuk menemukan bug ataupun error yang terjadi sebelum sistem berjalan secara live. Pengujian alpha dilakukan bersama dengan user dengan melakukan pencatatan setiap aktivitas yang dilakukan user dalam menjalankan system [14]. Tahap ini penliti melakukan pengujian sistem informasi yang telah dibangun. Pengujian ini dilakukan untuk melihat apakah ada bug yang terjadi sebelum sistem informasi diimplementasikan. Peneliti menggunakan alpha testing untuk melihat prilaku yang tidak normal pada sistem informasi. Berikut ini merupakan beberapa contoh pengujian yang telah dilakukan.

\section{Tabel 14 Pengujian login}

\begin{tabular}{llll}
\hline \hline Kelas Uji & $\begin{array}{l}\text { Data yang } \\
\text { dimasukan }\end{array}$ & Hasil & Kesimpulan \\
\hline $\begin{array}{l}\text { Konfirmasi } \\
\text { Halaman }\end{array}$ & $\begin{array}{l}\text { Nama pengguna } \\
\text { dan kata sandi }\end{array}$ & $\begin{array}{l}\text { Masuk ke } \\
\text { halaman } \\
\text { login dan }\end{array}$ & Sesuai \\
berhasil & \\
memasukkan & \\
& & nama & \\
& & penggun dan & \\
& & kata sandi & \\
\hline Konfirmasi & Nama_pengguna & Pernyataan & Sesuai \\
Halaman & dan kata sandi & muncul & \\
Masuk & & karena nama & \\
& & pengguna, & \\
& & kata sandi & \\
& & berbeda atau & \\
& & salah & \\
\hline
\end{tabular}

Tabel 14 merupakan pegujian untuk melakukan halaman login. Pengujian pada kolom pertama untuk

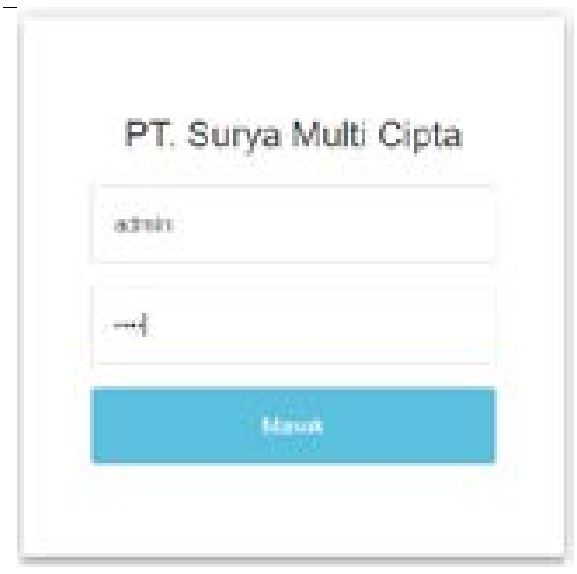

Gambar 22 Pengujian 1 mengecek apakah kolom untuk nama pengguna dan kata sandi dapat masukan atau tidak, dapat dilihat pada Gambar 22. Pengujian pada kolom kedua untuk mengecek apakah notifikasi akan muncul jika salah memasukan nama pengguna atau kata sandi yang dapat dilihat pada Gambar 25.

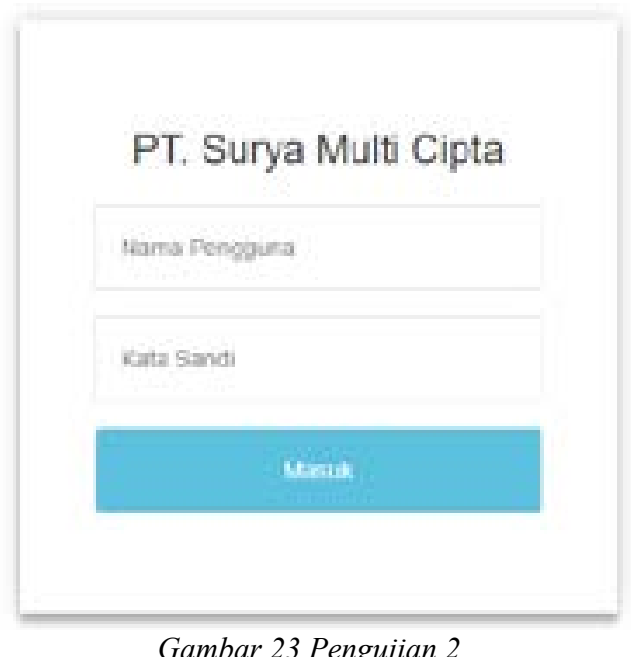

Tabel 15 Pengujian login admin

\begin{tabular}{llll}
\hline \hline Kelas Uji & $\begin{array}{l}\text { Data yang } \\
\text { dimasukan }\end{array}$ & Hasil & Kesimpulan \\
\hline Konfirmasi & Nama & Masuk ke & Sesuai \\
Halaman & pengguna, & halaman & \\
Masuk & $\begin{array}{l}\text { kata sandi } \\
\text { dari setiap } \\
\text { pengguna }\end{array}$ & $\begin{array}{l}\text { login dan } \\
\text { berhasil } \\
\text { memasukkan }\end{array}$ & \\
& & nama & \\
& & $\begin{array}{l}\text { pengguna } \\
\text { dan kata }\end{array}$ & \\
& & sandi & \\
& & $\begin{array}{l}\text { Dapat } \\
\text { menampilkan }\end{array}$ & Sesuai \\
Menampilkan & Nama & \\
Menu & pengguna, & menu & \\
penjualan, & kata sandi \\
customer, & dari setiap & penjualan, & \\
karyawan, & pengguna & customer, & \\
pengguna, & & karyawan, & \\
mesin, & & pengguna, & \\
supplier, dan & & mesin, & \\
laporan & & supplier, dan & \\
& & laporan & \\
\hline
\end{tabular}

Tabel 15 merupakan pegujian untuk melakukan halaman login. Pengujian pada kolom pertama untuk mengecek apakah kolom untuk nama pengguna dan kata sandi dapat masukan atau tidak dan dapat masuk ke menu utama, dapat dilihat pada Gambar 24. Pengujian pada kolom kedua untuk mengecek apakah setelah melakukan login sebagai admin akan masuk ke menu utama dan muncul menu penjualan, customer, karyawan, pengguna, mesin, supplier, dan laporan yang dapat dilihat pada Gambar 25.

Tabel 16 merupakan pegujian untuk melakukan halaman login. Pengujian pada kolom pertama untuk mengecek apakah kolom untuk nama pengguna dan kata sandi dapat masukan atau tidak dan dapat 


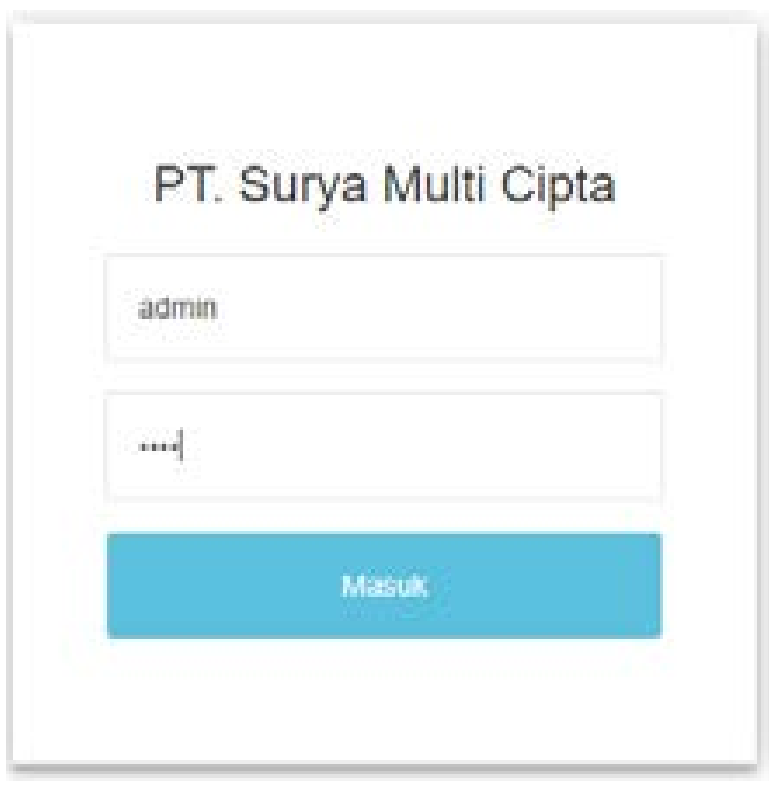

Gambar 24 Pengujian 3

\begin{tabular}{|c|c|c|c|}
\hline netionits & & & - \\
\hline$=$ & & & \\
\hline . & & & \\
\hline :- & & & \\
\hline$=$ & PT SUR & 'A MULTI & CIPTA \\
\hline & Gambar 2 & Pengujian 4 & \\
\hline abel to reng & $\operatorname{gin} P r$ & ement & \\
\hline Kelas Uji & $\begin{array}{l}\text { Data yang } \\
\text { dimasukan }\end{array}$ & Hasil & Kesimpulan \\
\hline $\begin{array}{l}\text { Konfirmasi } \\
\text { Halaman } \\
\text { Masuk }\end{array}$ & $\begin{array}{l}\text { Nama } \\
\text { pengguna, } \\
\text { kata sandi } \\
\text { dari setiap } \\
\text { pengguna }\end{array}$ & $\begin{array}{l}\text { Masuk ke } \\
\text { halaman } \\
\text { login dan } \\
\text { berhasil } \\
\text { memasukkan } \\
\text { nama } \\
\text { pengguna } \\
\text { dan kata } \\
\text { sandi }\end{array}$ & Sesuai \\
\hline $\begin{array}{l}\text { Menampilkan } \\
\text { menu mesin } \\
\text { dan supplier }\end{array}$ & $\begin{array}{l}\text { Nama } \\
\text { pengguna, } \\
\text { kata sandi } \\
\text { dari setiap } \\
\text { pengguna }\end{array}$ & $\begin{array}{l}\text { Dapat } \\
\text { menampilkan } \\
\text { menu mesin } \\
\text { dan supplier }\end{array}$ & Sesuai \\
\hline
\end{tabular}

masuk ke menu utama, dapat dilihat pada Gambar 26. Pengujian pada kolom kedua untuk mengecek apakah setelah melakukan login sebagai admin akan masuk ke menu utama dan muncul menu supplier dan mesin yang dapat dilihat pada Gambar 27.

Tabel 17 merupakan pegujian untuk melakukan halaman login. Pengujian pada kolom pertama untuk mengecek apakah kolom untuk nama pengguna dan kata sandi dapat masukan atau tidak dan dapat masuk ke menu utama, dapat dilihat pada Gambar 28. Pengujian pada kolom kedua untuk mengecek apakah setelah melakukan login sebagai admin akan masuk ke menu utama dan muncul menu penjualan, customer dan laporan yang dapat dilihat pada Gambar 29.

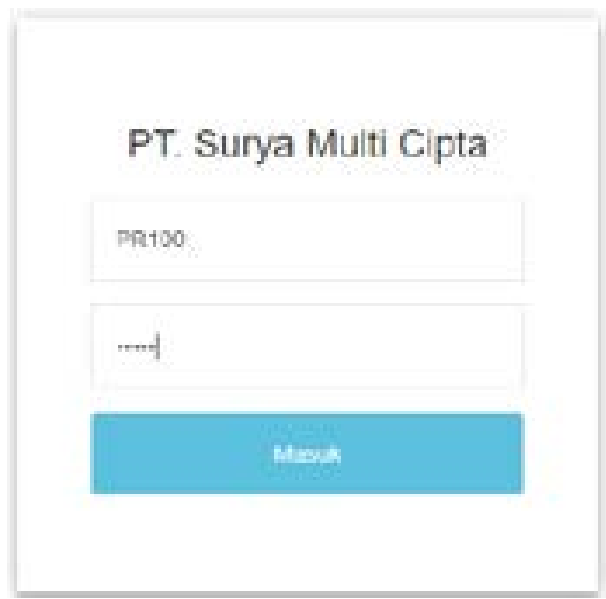

Gambar 26 Pengujian 5

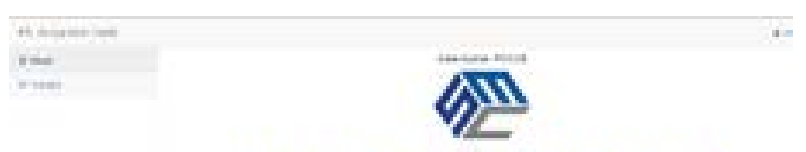

PT SURYA MULTI CIPTA

Gambar 27 Pengujian 6

Tabel 17 Penguiian login sales

\begin{tabular}{llll}
\hline \hline Kelas Uji & $\begin{array}{l}\text { Data yang } \\
\text { dimasukan }\end{array}$ & Hasil & Kesimpulan \\
\hline $\begin{array}{l}\text { Konfirmasi } \\
\text { Halaman }\end{array}$ & $\begin{array}{l}\text { Nama } \\
\text { pengguna, }\end{array}$ & $\begin{array}{l}\text { Masuk ke } \\
\text { halaman }\end{array}$ & Sesuai \\
Masuk & $\begin{array}{l}\text { kata sandi } \\
\text { dari setiap }\end{array}$ & $\begin{array}{l}\text { login dan } \\
\text { berhasil } \\
\text { memasukkan }\end{array}$ & \\
& & nama & \\
& & pengguna dan & \\
& & kata sandi & \\
\hline $\begin{array}{l}\text { Menampilkan } \\
\text { menu }\end{array}$ & Nama & Menampilkan & Sesuai \\
penjualan, & kengguna, & menu & \\
customer dandi & dari setiap & penjualan, & \\
laporan & pengguna dan & laporan & \\
\hline
\end{tabular}

Tabel 18 merupakan pegujian untuk melakukan halaman login. Pengujian pada kolom pertama untuk mengecek apakah kolom untuk nama pengguna dan kata sandi dapat masukan atau tidak dan dapat masuk ke menu utama, dapat dilihat pada Gambar 30. Pengujian pada kolom kedua untuk mengecek apakah setelah melakukan login sebagai admin akan masuk ke menu utama dan muncul menu penjualan, customer, pengguna, karyawan, mesin, supplier dan laporan yang dapat dilihat pada Gambar 31.

\section{G. Implementasi}

Peneliti mengimplementasikan sistem secara langsung dengan melakukan hosting setelah dilakukan alpha testing. Peneliti memilih menerapkan secara langsung karena belum adanya sistem informasi yang berjalan pada PT Surya Multi Cipta. Berikut merupakan hal yang dilakukan untuk implementasi. 


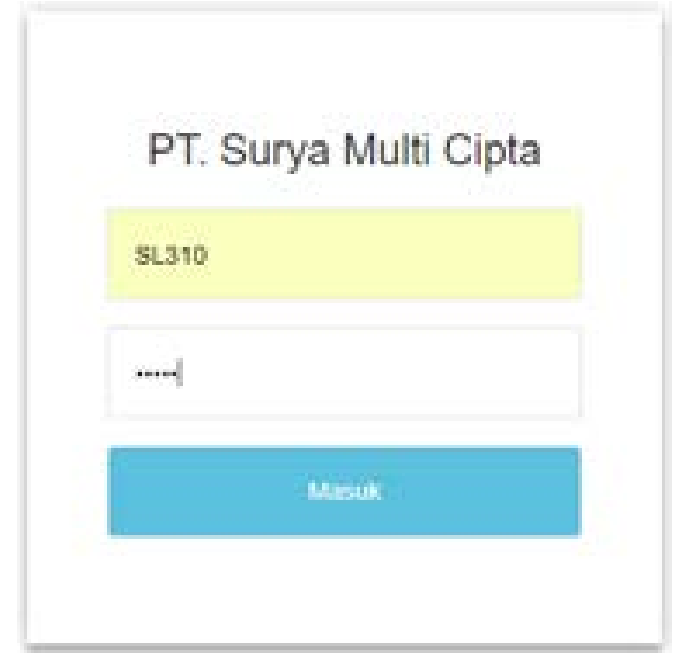

Gambar 28 Pengujian 7

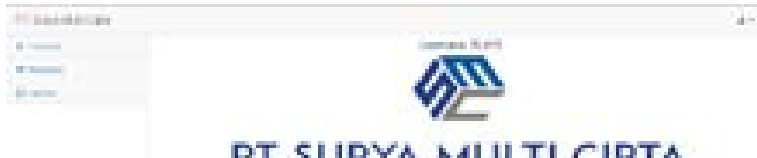

Gambar 29 Pengujian 8

Tabel 18 Pengujian login pemilik

\begin{tabular}{|c|c|c|c|}
\hline Kelas Uji & $\begin{array}{l}\text { Data yang } \\
\text { dimasukan }\end{array}$ & Hasil & Kesimpulan \\
\hline $\begin{array}{l}\text { Konfirmasi } \\
\text { Halaman } \\
\text { Masuk }\end{array}$ & $\begin{array}{l}\text { Nama } \\
\text { pengguna, } \\
\text { kata sandi } \\
\text { dari setiap } \\
\text { pengguna }\end{array}$ & $\begin{array}{l}\text { Masuk ke } \\
\text { halaman } \\
\text { login dan } \\
\text { berhasil } \\
\text { memasukkan } \\
\text { nama } \\
\text { pengguna dan } \\
\text { kata sandi }\end{array}$ & Sesuai \\
\hline $\begin{array}{l}\text { Menampilkan } \\
\text { Menu } \\
\text { penjualan, } \\
\text { customer, } \\
\text { karyawan, } \\
\text { mesin, } \\
\text { supplier, dan } \\
\text { laporan }\end{array}$ & $\begin{array}{l}\text { Nama } \\
\text { pengguna, } \\
\text { kata sandi } \\
\text { dari setiap } \\
\text { pengguna }\end{array}$ & $\begin{array}{l}\text { Menampilkan } \\
\text { menu } \\
\text { penjualan, } \\
\text { customer, } \\
\text { karyawan, } \\
\text { mesin, } \\
\text { supplier, dan } \\
\text { laporan }\end{array}$ & Sesuai \\
\hline
\end{tabular}

Membeli hosting dan domain dengan nama www. suryamulticipta.com; Memindahkan dokumen yang

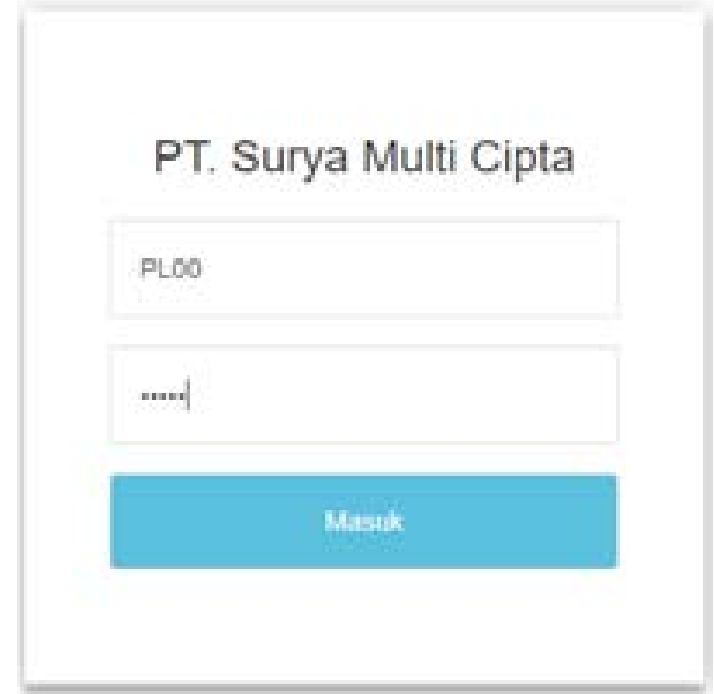

Gambar 30 Pengujian 9

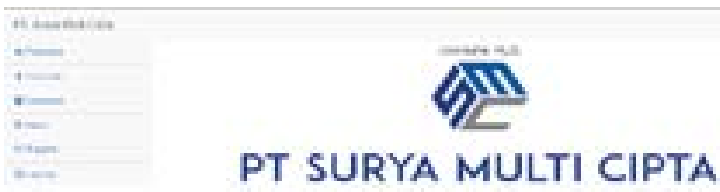

Gambar 31 Pengujian 10

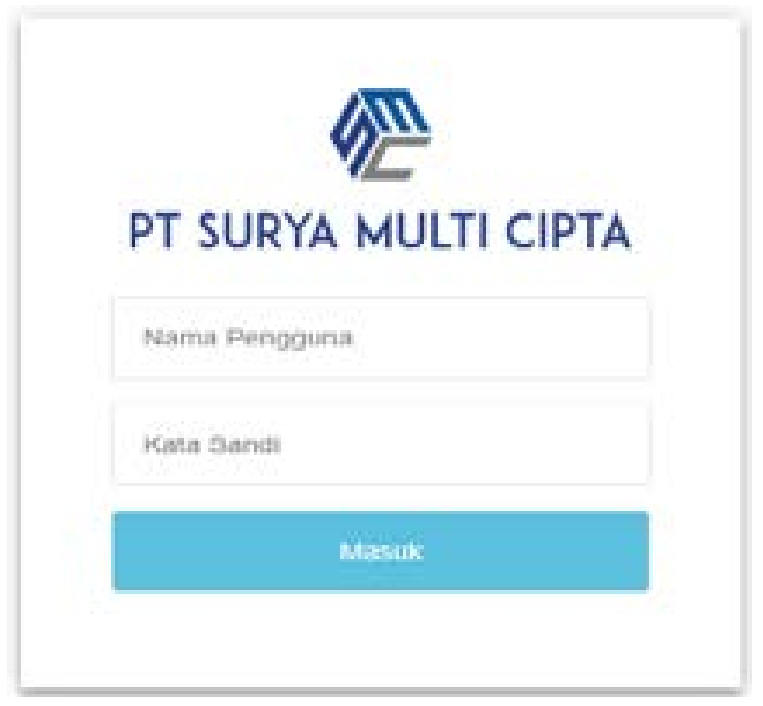

Gambar 32 Halaman login

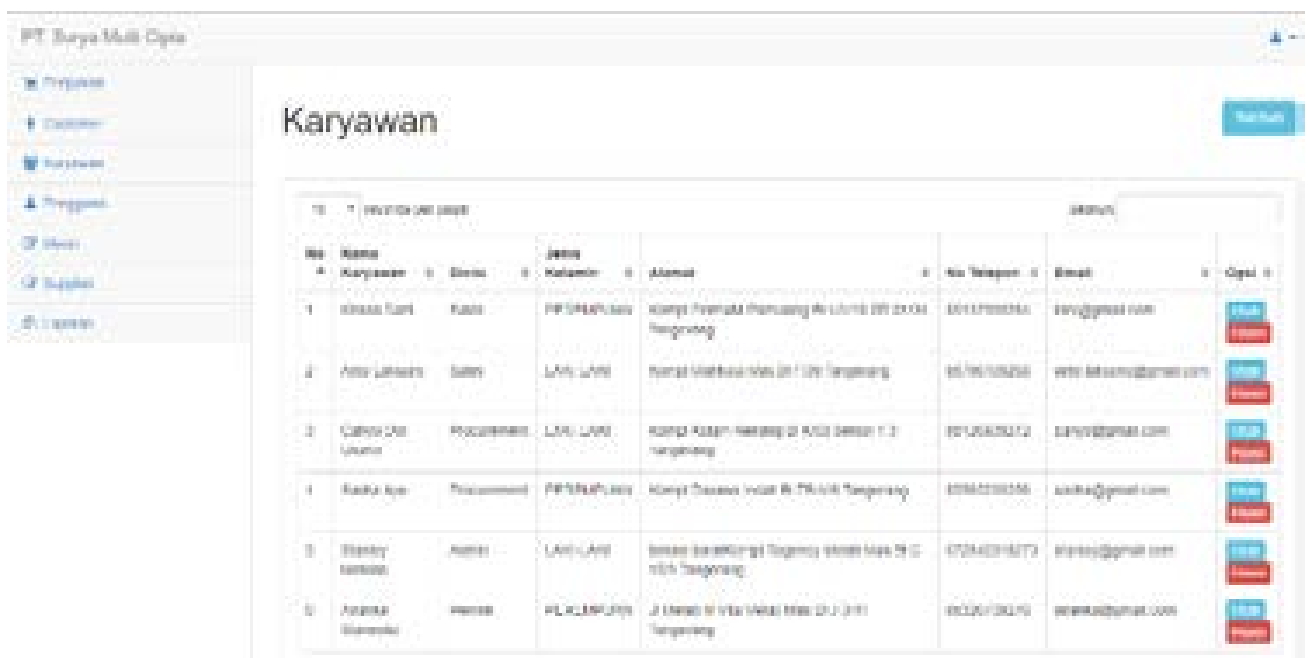



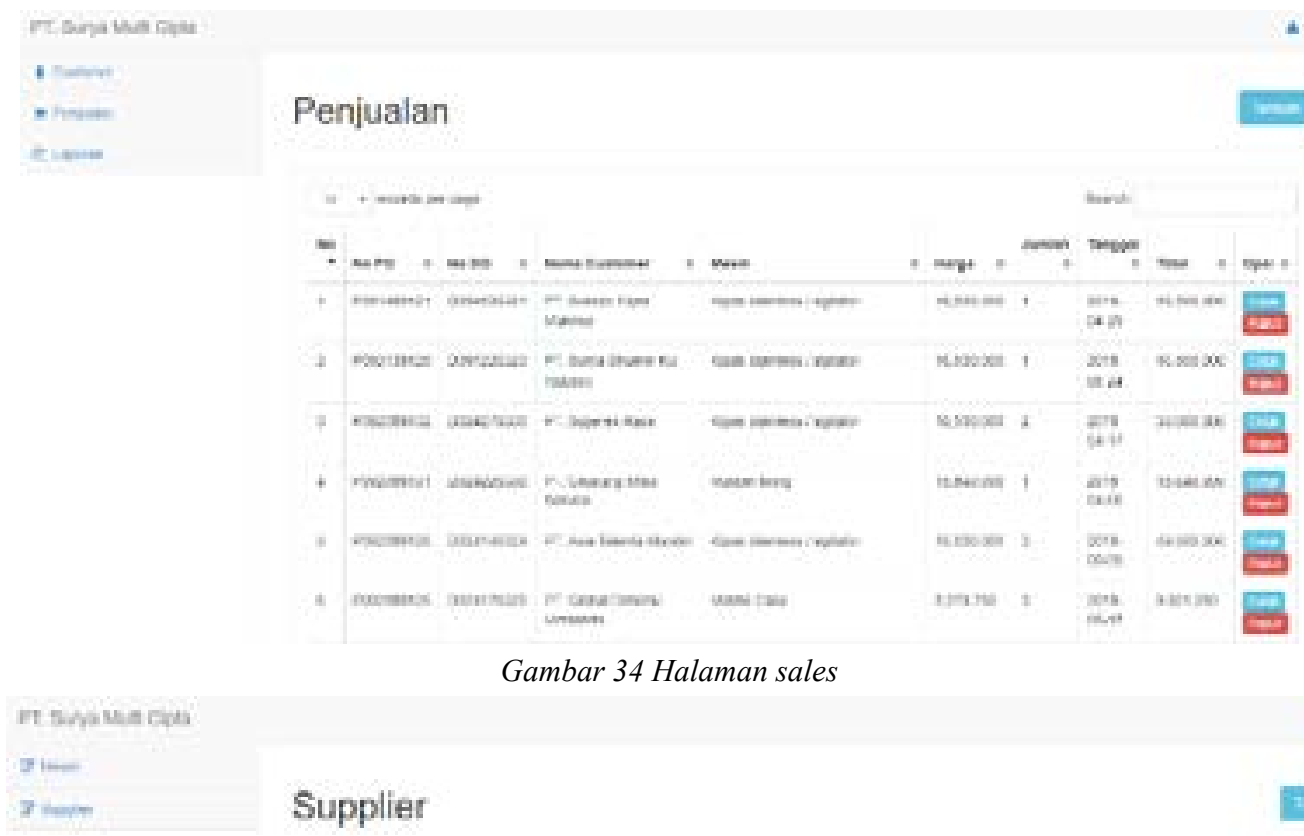

Gambar 34 Halaman sales

\section{Supplier}

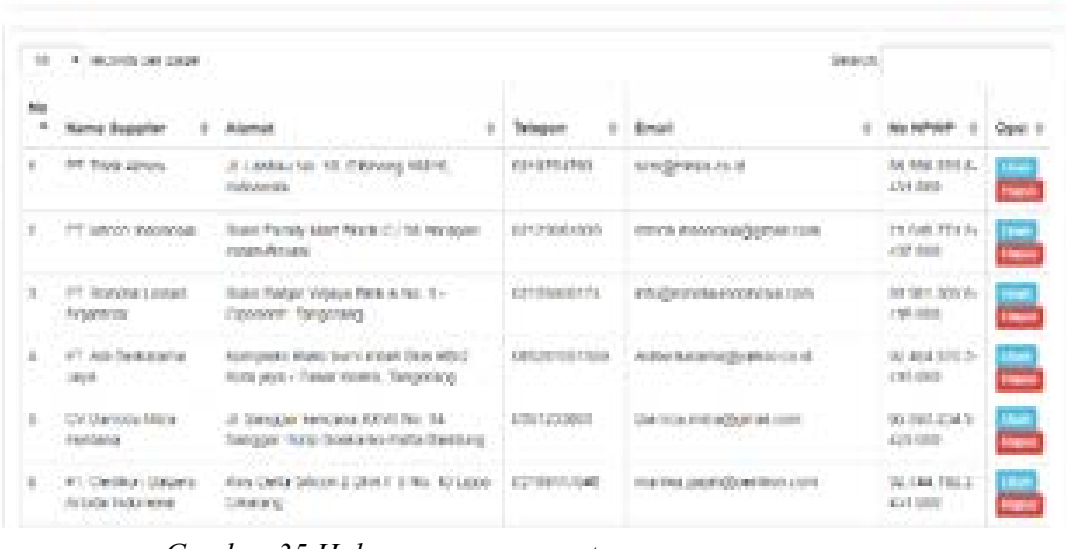

Gambar 35 Halaman procurement

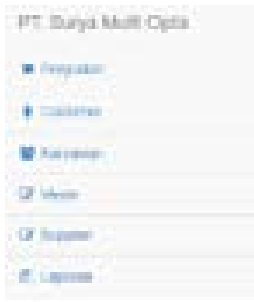

Laporan

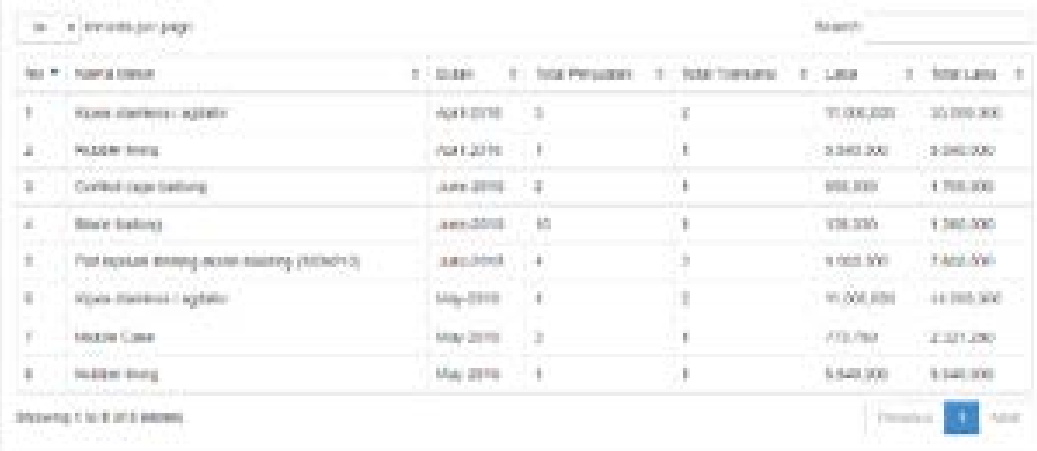

Gambar 36 Halaman pemilik

berisi pengkodean ke dalam hosting; Membuat database baru dan mengeksport isi database lama ke database baru; dan Memasukan data-data PT Surya Multi Cipta ke sistem informasi penjualan

Berikut ini merupakan hasil dari implementasi yang telah dilakukan, terdapat pada Gambar sampai Gambar 32 sampai Gambar 36. Gambar 32 merpakan tampilan halaman untuk login terdapat kolom untuk memasukan pengguna dan kata sandi. Gambar 33 merupakan tampilan untuk Admin setelah melakukan login, Admin dapat mengakses menu penjualan, customer, karyawan, pengguna, supplier, mesin dan laporan. Gambar 34 merupakan tampilan untuk Sales setelah melakukan login, Sales dapat mengakses menu penjualan, customer dan laporan. Gambar 35 merupakan tampilan untuk Procurement setelah 
melakukan login, Procurement dapat mengakses menu mesin dan supplier. Gambar 36 merupakan tampilan untuk Pemilik setelah melakukan login, Pemilik dapat mengakses menu penjualan, customer, karyawan, pengguna, mesin, supplier dan laporan. Pemilik tidak dapat menambah, mengubah, ataupun menghapus data di setiap menu, pada menu penjualan Pemilik dapat mencetak untuk hasil penjualan yang telah dilakukan.

\section{SIMPULAN}

Penelitian ini menghasilkan Sistem Informasi Penjualan PT Surya Multi Cipta berbasis website. Sistem ini menghubungkan bagian sales dengan procurement untuk kepentingan penjualan. Sistem informasi penjualan mengintegrasikan antara mesin, supplier, customer, dan penjualan. sistem dapat mengotomasi untuk pencatatan penjualan yang terjadi setiap bulan. Sistem ini dapat membantu karyawan dalam melakukan pencatatan penjualan dan pembuatan laporan bulanan. Pengembangan sistem untuk kedepannya dapat dilakukan penambahan beberapa modul yang saling terintegrasi dengan penjualan.

\section{DAFTAR RUJUKAN}

[1] A. Kadir, "Pengertian Sistem Informasi," in Pengenalan Sistem Informasi, Yogyakarya, ANDI OFFSET, 2014, pp. 8 - 10 .

[2] Y. R. Dede Wahyudi Setiawan, "Implementing enterprise resource planning (ERP) in sales information system (SIS) of SME (small medium enterprise) Abo Farm Indonesia," in 2014 International Conference on ICT For Smart Society, Bandung, 2014.

[3] K. Rainer \& H. Watson, "Acquiring Information Systems and Applications," in Management Information Systems Moving Business Forward, vol. 2, Hoboken, John Wiley \& Sons, Inc, 2012, p. 507.
[4] S. H. Putri \& H. Mulyono, "Analisis dan Perancangan Sistem Informasi Penjualan berbasis Web studi kasus UD. CAKRA MOTOR,” Jurnal Manajemen Sistem Informasi, vol. 2, p. 821, 2017.

[5] S. Kosasi, "Perancangan Sistem Informasi Penjualan Berbasis Web Dalam Memasarkan Mobil Bekas," Citec Journal, vol. 3, p. 1, 2015.

[6] H. S. Utomo, R. Sayydati \& O. Rahmanto, "Implementation of Mobile-Based Monitoring Sales System in Semi Tani Shop," in International Conference on Sustainable Information Engineering and Technology, Malang, 2017.

[7] R. A. Sukamto \& M. Salahuddin, "Use Case Diagram," in Rekayasa Perangkat Lunak Terstruktur dan Berorientasi Objek, Bandung, INFORMATIKA, 2014, p. 155.

[8] R. A. Sukamto \& M. Salahuddin, "Class Diagram," in Rekayasa Perangkat Lunak Terstruktur dan Berorientasi Objek, Bandung, INFORMATIKA, 2014, pp. 141-144.

[9] R. A. Sukamto \& M. Salahiddun, “Activity Diagram,” in Rekayasa Perangkat Lunak Terstruktur dan Berorientasi Objek, Bandung, INFORMATIKA, 2014, pp. 161-162.

[10] R. A. Sukamto \& M. Salahuddin, "Sequence Diagram," in Rekayasa Perangkat Lunak Terstruktur dan Berorientasi Objek, Bandung, INFORMATIKA, 2014, p. 165.

[11] Fathansyah, "Apa itu Basis Data," in Basis Data, Bandung, INFORMATIKA, 2012, pp. 2-3.

[12] R. A. Sukamto \& M. Salahuddin, "CDM," in Rekayasa Perangkat Lunak Terstruktur dan Berorientasi Objek, Bandung, INFORMATIKA, 2015, pp. 59-61.

[13] R. A. Sukamto \& M. Salahuddin, "PDM," in Rekayasa Perangkat Lunak Terstruktur dan Berorientasi Objek, Bandung, INFORMATIKA, 2015, p. 63.

[14] J. Simarmata, in Rekayasa Perangkat Lunak, Yogyakarta, ANDI OFFSET, 2010, p. 321. 